\title{
Spirulina platensis Growth in Open Raceway Ponds Using Fresh Water Supplemented with Carbon, Nitrogen and Metal Ions
}

\author{
Jorge Alberto Vieira Costa*, Luciane Maria Colla, and Paulo Duarte Filho \\ Laboratório de Engenharia Bioquímica, Departamento de Química, Fundação Universidade \\ Federal do Rio Grande, Caixa Postal 474, CEP 96201-900, Rio Grande, RS, Brasil. \\ Fax: +55-53-2338750. E-mail: dqmjorge@furg.br \\ * Author for correspondence and reprint requests \\ Z. Naturforsch. 58c, 76-80 (2003); received July 1/August 19, 2002 \\ To investigate the feasibility of using fresh water from Mangueira Lagoon (Rio Grande \\ do Sul, Brazil) for biomass production in open raceway ponds $(0.7 \mathrm{~m}$ long, $0.18 \mathrm{~m}$ wide, \\ $0.075 \mathrm{~m}$ deep) we studied the influence of nutrient addition (carbon as sodium bicarbonate, \\ nitrogen as urea, phosphate, sulfate, ferric iron, magnesium and potassium) on the growth \\ rate of the cyanobacteria Spirulina platensis using a $2^{2}$ factorial design. In unsupplemented \\ lagoon water production of $S$. platensis was $0.78 \pm 0.01 \mathrm{~g} / \mathrm{l}$ (dry weight basis) while the addi- \\ tion of $2.88 \mathrm{~g} / \mathrm{l}$ of sodium bicarbonate (without added urea, phosphate, sulfate or metal ions) \\ resulted in $0.82 \pm 0.01 \mathrm{~g} / \mathrm{l}$ after 400 hours of culture. The further addition of phosphate and \\ metal ions resulted in growth for up to $750 \mathrm{~h}$ and a final $S$. platensis biomass of $1.23 \pm 0.04$ \\ to $1.34 \pm 0.03 \mathrm{~g} / \mathrm{l}$. \\ Key words: Cyanobacteria, Spirulina platensis, Urea
}

\section{Introduction}

Biotechnological processes based on cyanobacteria have been receiving increasing interest due to their potential to produce a diverse range of chemicals and biologically active compounds, such as vitamins, carotenoid pigments, proteins, lipids and polysaccharides (Zhang et al., 1999). For economic reasons, the culture system predominating in the large-scale commercial production of these types of organisms is the open-air system, closed systems being very expensive and often difficult to scale up (Borowitzka, 1999).

The cyanobacterium Spirulina platensis has been commercially exploited for the production of human food supplements, animal feed and pharmaceuticals because of its ability to produce large quantities of valuable products, such as phycocyanin (Estrada et al., 2001; Miranda et al., 1998; Sarada et al., 1998) and $\omega-3$ and $\omega-6$ polyunsaturated fatty acids (Alonso and Maroto, 2000; Deshnium et al., 2000; Marquez et al., 1995; Quoc et al., 1994; Cohen et al., 1993).

Spirulina platensis is a multicellular, filamentous cyanobacterium, consisting of blue-green filaments of cylindrical cells ( 1 to $12 \mu \mathrm{m}$ diameter) in unbranched helicoidal trichomes, the filaments be- ing motile, gliding along their axis, and have no heterocysts (Richmond, 1990). Spirulina can colonize environments that are unsuitable for many other organisms, forming populations in freshwater and brackish lakes and some marine environments, mainly alkaline saline lakes (Belov and Giles, 1997; Richmond, 1990).

The large-scale production of Spirulina biomass depends on many factors, the most important of which are nutrient availability, temperature and light. These factors can influence the growth of Spirulina and the composition of the biomass produced by causing changes in metabolism, which considerably modify the time course of the accumulation of the main biomass components (Cornet et al., 1992). Carbon is the principal nutrient required by Spirulina, and in alkaline lakes this organism is the dominant species because of the presence of high concentrations of sodium carbonate. Vonshak (1997) has shown that, after labor, the second major cost in Spirulina biomass production is the cost of nutrients, principally the carbon source.

Mangueira Lagoon is $92 \mathrm{~km}$ long by $7.6 \mathrm{~km}$ wide with a minimum depth of $1.2 \mathrm{~m}$ and a maximum depth of $7.4 \mathrm{~m}$. It is located in the southern of Brazilian state of Rio Grande do Sul, between the At- 
lantic Ocean and Mirim Lagoon and represents an important hydrobiology resource that is used principally as a source of water for paddy-rice. The pH 8.03 (Costa et al., 2002) and other physicochemical characteristics of Mangueira Lagoon are ideal for the culture of Spirulina species.

The aim of this work was to study the growth of Spirulina platensis in small open raceway ponds using fresh water from Mangueira Lagoon and to investigate the effect of adding of nutrients to the water in an attempt to prevent nutrient depletion and increase the biomass production of Spirulina platensis.

\section{Materials and Methods}

\section{Microorganism and culture medium}

The cyanobacterium used in this study was Spirulina platensis strain LEB-52 (Costa et al., 2001). Zarrouk's medium (Zarrouk, 1966; Vonshak, 1982) being used to prepare and maintain the cultures. Water from Mangueira Lagoon was supplemented with nutrients, initial experiments being made with unsupplemented lagoon water and lagoon water supplemented with $2.88 \mathrm{~g} / \mathrm{l}$ of sodium bicarbonate or $0.35 \mathrm{~g} / 1$ urea or both. Further experiments were made using lagoon water (with and without added bicarbonate or urea) supplemented with various combinations of the nutrients contained in Zarrouk's medium (Table I).

Table I. Nutrient supplementation of lagoon water for experiments 1 to 8 .

\begin{tabular}{ll}
\hline Nutrient & Supplementation \\
\hline $\mathrm{KH}_{2} \mathrm{PO}_{4}$ & $0.5 \mathrm{~g} / 1$ for experiments 5,7 \\
$\mathrm{~K}_{2} \mathrm{SO}_{4}$ & $1.0 \mathrm{~g} / 1$ for experiments 5,7 \\
$\mathrm{MgSO}_{4} \cdot 7 \mathrm{H}_{2} \mathrm{O}$ & $0.2 \mathrm{~g} / 1$ for experiments 6,8 \\
$\mathrm{FeSO}_{4} \cdot 7 \mathrm{H}_{2} \mathrm{O}$ & $0.1 \mathrm{~g} / 1$ for experiments 6,8 \\
$\mathrm{NaHCO}_{3}$ & $2.88 \mathrm{~g} / 1$ for experiments $2,4,7,8$ \\
$\mathrm{NH}_{2} \mathrm{CONH}_{2}$ & $0.35 \mathrm{~g} / 1$ for experiments $3,4,7,8$ \\
(urea) & \\
No addition & Experiment 1 \\
\hline
\end{tabular}

\section{Culture conditions}

Experiments were carried out in a greenhouse in PVC open raceways $(0.7 \mathrm{~m}$ long, $0.18 \mathrm{~m}$ wide, $0.075 \mathrm{~m}$ deep) containing 5 liters of $S$. platensis culture with an initial biomass concentration of $0.1 \mathrm{~g} / \mathrm{l}$ (Costa et al., 2000). The cultures were mixed using paddle wheels turning at 18 revs $\mathrm{min}^{-1}$ and illuminated with daylight-type fluorescent lights (Osram, $40 \mathrm{~W}$, Brazil) at an intensity of 1,900 lux and a $12 \mathrm{~h}$ light/dark photoperiod at $30^{\circ} \mathrm{C}$ (Sarada et al., 1999; Zhang et al., 1999).

\section{Chemical and microbiological analysis}

Samples were taken aseptically every $24 \mathrm{~h}, \mathrm{pH}$ being measured potentiometrically and biomass determined by optical density at $670 \mathrm{~nm}$ using a VARIAN model CARY 100 spectrophotometer. Carbonate and bicarbonate concentrations were assessed weekly according to standard methods (AOAC, 1995). Each experiment was checked for bacterial contamination after 360 hours of cultivation using the total pour-plate method and plate count agar (ABNT, 1991), the results being reported as colony forming units per $\mathrm{ml}(\mathrm{CFU} / \mathrm{ml})$.

\section{Experimental design and statistical analysis}

The study was separated into two stages, each containing four experiments. In the first stage we used a $2^{2}$ factorial design to study the effects of the addition of sodium bicarbonate and urea to lagoon water on the growth rate and biomass concentration of Spirulina platensis, the resultant data being subjected to analysis of variance. In the second stage, the influence of adding various combinations of the components of Zarrouk's medium (Table I) was studied, this data being analyzed by the method described by Zar (1984). This technique detecting differences between regression lines using analysis of covariance through the statistical test of equation 1 , where SSc = sum of common residual squares, $\mathrm{SSp}=$ sum of pooled residual squares and DFp = degrees of freedom of the pooled residual. When the hypothesis that all slopes were equal was rejected a multiple comparison test (Tukey test, 95\% confidence interval) was used to determine which of the $\mathrm{K}$ population slopes differed from the others and thus detect differences between each pair of slopes.

$$
F=\frac{\frac{[S S c-S S p]}{[K-1]}}{\frac{S S P}{D F p}}
$$




\section{Results and Discussion}

\section{Microbiological analysis}

The results of microbiological analysis showed that the levels of bacterial contamination in all experiments $\left(<1.6 \times 10^{4} \mathrm{CFU} / \mathrm{ml}\right)$ were smaller than that previously described for dried Spirulina. It should also be remembered that these counts were taken before drying of the Spirulina culture and that the drying process would probably decreases the level of contamination. In large-scale culture, especially in open ponds, there is a greater susceptibility to bacterial contamination. Vonshak (1997) reported that the standard plate count limits for dried Spirulina are $<0.1 \times 10^{6} \mathrm{CFU} / \mathrm{g}$ in France, $<10 \times 10^{6} \mathrm{CFU} / \mathrm{g}$ in Sweden, < $0.05 \times 10^{6} \mathrm{CFU} / \mathrm{g}$ in Japan and $<1 \times 10^{6} \mathrm{CFU} / \mathrm{g}$ for Spirulina produced by Earthrise Farms (California, EUA) a large producer of products based on this organism.

\section{Growth curves and statistical analysis}

The water from Mangueira Lagoon already contained levels of carbon $\left(0.126 \mathrm{HCO}_{3}{ }^{-2} \mathrm{~g} / \mathrm{l}\right)$ and nitrogen $\left(0.132 \mathrm{mg} / \mathrm{l} \mathrm{NH}_{4}{ }^{+}, 0.0195 \mathrm{mg} / \mathrm{l} \quad \mathrm{NO}_{2}{ }^{-}\right.$, $1.040 \mathrm{mg} / \mathrm{l} \mathrm{NO}_{3}{ }^{-}$- Costa et al., 2002). We chose urea $\left(\mathrm{CH}_{4} \mathrm{~N}_{2} \mathrm{O}\right)$ as supplementary nitrogen source due to the fact that it is cheaper than other nitrogen sources (e.g. potassium nitrate, sodium nitrate or ammonium chloride) and contains two nitrogen atoms (46\% nitrogen) whereas nitrates have only one (14-16\% nitrogen) (Faintuch et al., 1992). Urea is a good nitrogen source for Spirulina, producing no ill effects at $\mathrm{pH} 8.4$ as long as its concentration is kept below $1.5 \mathrm{~g} / \mathrm{l}$ (Richmond, 1990). The maximum levels of urea and sodium bicarbonate were based on a previous study (in Erlenmeyer flasks) on the growth of Spirulina platensis using water from Mangueira Lagoon (Costa et al., 2002).

Table II shows the results of maximum biomass concentration $\left(\mathrm{X}_{\max }\right)$, maximum specific growth rate $\left(\mu_{\max }\right)$ and doubling time $\left(t_{d}\right)$, being the specific growth rate and doubling time calculated during the exponential growth phase.

In Table II, experiment 1 represents the control with no added nutrients while experiment 3 used lagoon water supplemented with $0.35 \mathrm{~g} / 1$ urea. It can be seen that the these experiments presented similar values of maximum biomass concentration $(0.78 \mathrm{~g} / \mathrm{l})$ for $\mathrm{X}_{\max }$, although for experiment $1 \mu_{\max }$ is 0.1394 /day while for experiment 3 it is 0.1573 / day (Table II), which is significantly different at $p=0.0002$ and it appears that the addition of urea at this concentration was beneficial in promoting biomass production by $S$. platensis. This agrees with the results of Richmond (1990), who reported that Spirulina produced $0.32 \mathrm{~g} / 1$ of biomass with $0.06 \mathrm{~g} / \mathrm{l}$ of urea, $1.16 \mathrm{~g} / \mathrm{l}$ with $0.3 \mathrm{~g} / \mathrm{l}$ of urea and $0.51 \mathrm{~g} / 1$ with $1.2 \mathrm{~g} / 1$ of urea.

In experiment 2 only sodium bicarbonate was added, but the biomass production $\left(\mathrm{X}_{\max }\right)$ was higher than in the other experiments, being $0.82 \mathrm{~g} / \mathrm{l}$ compared with 0.78 and $0.79 \mathrm{~g} / \mathrm{l}$ up to $400 \mathrm{~h}$ of culture. The maximum specific growth rate of experiment $2(0.1357 /$ day $)$ was significantly $(\mathrm{p}=0.0002)$ smaller than the $\mu_{\max }$ of experiment $1(0.1394 /$ day). According to Vonshak et al. (1982), higher specific growth rates are to be expected in systems that are primarily light-limited. However, the relative effect of decreasing the population density, and thus increasing the availability of light to each cell, is more significant at higher temperatures, although this didn't occur in our experiments, be-

Table II. Growth parameters Spirulina platensis in lagoon water supplemented and unsupplemented with sodium bicarbonate $\left(\mathrm{NaHCO}_{3}\right)$ and urea.

\begin{tabular}{lccccccc}
\hline Run & $\begin{array}{c}\mathrm{NaHCO}_{3} \\
(\mathrm{~g} / \mathrm{l})\end{array}$ & $\begin{array}{c}\mathrm{Urea} \\
(\mathrm{g} / \mathrm{l})\end{array}$ & $\mathrm{X}_{\max }{ }^{\mathrm{a}}$ & $\mu_{\max }{ }^{\mathrm{b}}$ & $\mathrm{t}_{\mathrm{d}}{ }^{\mathrm{c}}$ & $\Delta \mathrm{t}^{\mathrm{d}}$ & $\mathrm{r}^{2 \mathrm{e}}$ \\
\hline 1 & 0.0 & 0.0 & $0.78 \pm 0.01$ & $0.1394 \pm 0.0001$ & 4.97 & $48-360$ & 0.967 \\
2 & 2.88 & 0.0 & $0.82 \pm 0.01$ & $0.1357 \pm 0.0001$ & 5.11 & $48-408$ & 0.965 \\
3 & 0.0 & 0.35 & $0.78 \pm 0.01$ & $0.1573 \pm 0.0002$ & 4.41 & $96-360$ & 0.990 \\
4 & 2.88 & 0.35 & $0.79 \pm 0.01$ & $0.0735 \pm 0.0001$ & 9.43 & $144-384$ & 0.958 \\
\hline
\end{tabular}

${ }^{\mathrm{a}}$ Maximum concentration of Spirulina platensis (mean \pm standard deviation, g/l, dry weight basis); ${ }^{\mathrm{b}}$ Maximum specific growth rate (mean \pm standard deviation , $1 /$ day); ${ }^{\mathrm{c}}$ doubling time (1/day); ${ }^{\mathrm{d}}$ Length of exponential growth phase (hours); ${ }^{\mathrm{e}}$ correlation coefficient. 
cause the temperature remained constant at $30^{\circ} \mathrm{C}$. When both sodium bicarbonate and urea were added (experiment 4) the maximum specific growth rate was lowest at $0.0735 /$ day. Highest biomass production $\left(\mathrm{X}_{\max }\right)$ was obtained without addition of urea but with $2.88 \mathrm{~g} / \mathrm{l}$ of sodium bicarbonate, whereas the best $\mu_{\max }$ value was obtained with no addition of sodium bicarbonate but $0.35 \mathrm{~g} / \mathrm{l}$ of urea. When sodium bicarbonate was not added but the concentration of urea increased from 0 to $0.35 \mathrm{~g} / \mathrm{l}$ there was little change in $\mathrm{X}_{\max }$ and $\mu_{\max }$ but the addition of $2.88 \mathrm{~g} / \mathrm{l}$ of sodium bicarbonate and an increase in urea concentration from 0 to $0.35 \mathrm{~g} / 1$ resulted in a decrease in $\mathrm{X}_{\max }$ and $\mu_{\max }$. The high values obtained with the addition of sodium bicarbonate without urea may be the result of an increase in $\mathrm{pH}$ (alkalinity) due to the formation of a $\mathrm{CO}_{2} / \mathrm{H}_{2} \mathrm{CO}_{3} / \mathrm{HCO}_{3}{ }^{-} / \mathrm{CO}_{3}{ }^{-2}$ system, which is a very useful buffer system for maintained the alkaline $\mathrm{pH}$ which is important for the optimum growth of Spirulina and which helps to prevent carbon depletion (Vonshak, 1997; Richmond, 1990).

Figure 1 shows the results for experiments 5 to 8 in which lagoon water was supplemented with sulfate, phosphate, ferric iron, magnesium and potassium as well as carbon and nitrogen. The growth curves obtained presented the same behavior, and showed no lag phase. The ZAR method showed that the best biomass values occurred in experiment 8 when both bicarbonate and urea were added, the largest slope value being 0.155 $(p<0.05)$. The second best result occurring in experiment 7 , where the slope value was 0.144 ( $\mathrm{p}<$ $0.05)$. These results show that the addition of other nutrients in addition to sodium bicarbonate results in S. platensis growing for 750 hours with biomass concentrations reaching from 1.23 to $1.33 \mathrm{~g} / \mathrm{l}$, indi-

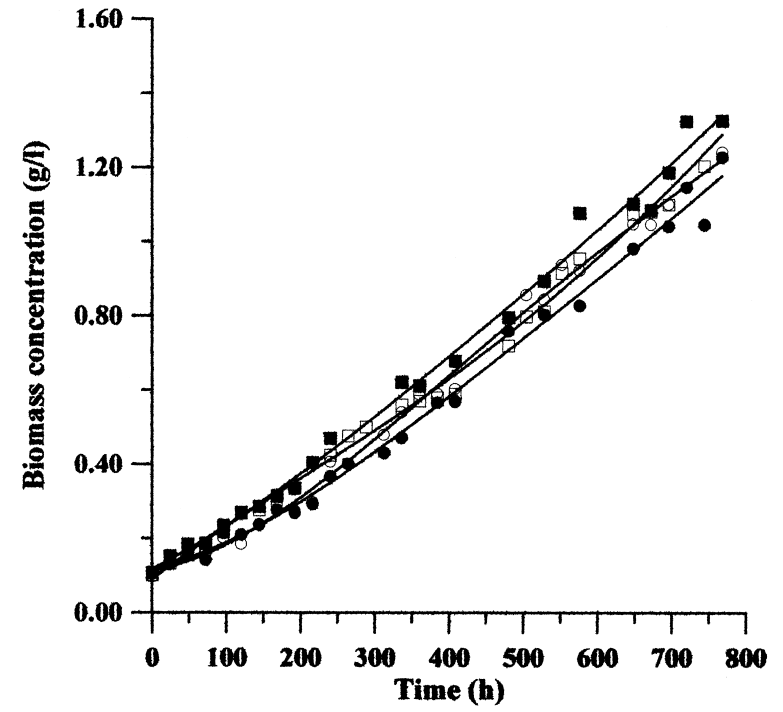

Fig. 1. Growth (g/l) of Spirulina platensis in unsupplemented lagoon water and lagoon water supplemented with sodium bicarbonate, urea, phosphate and metal ions. Supplement key: $=0.5 \mathrm{~g} / \mathrm{l}$ potassium dihydrogen phosphate and $1.0 \mathrm{~g} / 1$ potassium sulfate (experiment 5), $\mathrm{O}=0.2 \mathrm{~g} / \mathrm{l}$ magnesium sulfate and $0.01 \mathrm{~g} / \mathrm{l}$ ferric sulfate (experiment 6 ), $\boldsymbol{\square}=0.5 \mathrm{~g} / \mathrm{l}$ potassium dihydrogen phosphate, $1.0 \mathrm{~g} / \mathrm{l}$ potassium sulfate, $2.88 \mathrm{~g} / 1 \mathrm{NaHCO}_{3}$ and $0.35 \mathrm{~g} / \mathrm{l}$ urea (experiment 7), $\square=0.2 \mathrm{~g} / \mathrm{l}$ magnesium sulfate, $0.01 \mathrm{~g} / 1$ ferric sulfate, $2.88 \mathrm{~g} / 1 \mathrm{NaHCO}_{3}$ and $0.35 \mathrm{~g} / 1$ urea (experiment 8). Maximum biomass concentrations: experiment $5(1.23 \pm 0.04 \mathrm{~g} / \mathrm{l})$, experiment 6 (1.24 \pm $0.03 \mathrm{~g} / \mathrm{l})$, experiment $7(1.33 \pm 0.03 \mathrm{~g} / \mathrm{l})$ and experiment $8(1.31 \pm 0.06 \mathrm{~g} / \mathrm{l})$.

cating the need for additional of sources of potassium, sulfate, phosphate and metal ions.

\section{Acknowledgments}

The authors are grateful to Amana-Key Development Company and the Zero Emissions Research and Initiatives (ZERI) Foundation for financial support. 
Alonso D. and Maroto F. (2000), Plant as 'chemical factories' for the production of polyunsaturated fatty acids. Biotechnol. Adv. 18, 481-497.

AOAC (1995), Official Methods of Analysis, 16th Edition. Association of Official Analytical Chemists, Arlington, VA, USA, ISBN 0-935584-54-4.

ABNT (1991), Microrganismos viáveis, aeróbios e anaeróbios em alimentos: contagem padrão em placas. Associação Brasileira de Normas Técnicas, Rio de Janeiro-RJ, Brazil.

Belov A. P. and Giles J. D. (1997), Dynamical model buoyant cyanobacteria. Hydrobiology 349, 87-97.

Borowitzka M. (1999), Commercial production of microalgae: ponds, tanks, tubes and fermenters. J. Biotechnol. 70, 313-321.

Cohen Z., Reungjitchachawali M., Angdung W. and Tanticharoen M. (1993), Production and partial purification of $\gamma$-linolenic acid and some pigments from Spirulina platensis. J. Appl. Phycol. 5, 109-115.

Cornet J. F., Dussap C. G. and Dubertret G. (1992), A structured model for simulation of cultures of the cyanobacterium Spirulina platensis in photobioreactors: I.Coupling between light transfer and growth kinetics. Biotechnol. Bioeng. 40, 817-825.

Costa J. A. V., Colla L. M., Duarte P., Kabke K. and Weber A. (2002), Modelling of Spirulina platensis growth in fresh water using response surface methodology. World J. Microbiol. Biotechnol. In Press.

Costa J. A. V., Cozza K. L., Oliveira L. and Magagnin G. (2001), Different nitrogen sources and growth responses of Spirulina platensis in microenvironments. World J. Microbiol. Biotechnol. 17, 439-442.

Costa J. A. V., Linde G. A., Atala D. I. P., Mibieli G. M. and Krüger, R. T. (2000), Modelling of growth conditions for cyanobacterium Spirulina platensis in microcosms. World J. Microbiol. Biotechnol. 16, 15-18.

Deshnium P., Paithoonrangsarid K., Suphatrakul A., Meesapyodsuk D., Tanticharoen M. and Cheevadhanarak S. (2000), Temperature-independent and dependent expression of desaturase genes in filamentous cyanobacterium Spirulina platensis strain C1 (Arthospira sp. PCC 9438). FEMS Microbiol. Lett. 184, 207-213.

Estrada J. E., Bescós P. and Villar Del Fresno A. M. (2001), Antioxidant activity of different fractions of Spirulina platensis protean extract. Il Farmaco 56, 497-500.

Faintuch B. L., Sato S. and Aquarone E. (1992), Emprego de algumas fontes nitrogenadas na obtenção de biomassa de Oscillatoria limnetica. Revista Microbiologia 23, 32-36.

Marquez F., Sasaki K., Nishio N. and Nagai S. (1995), Inhibitory effect of oxygen accumulation on the growth of Spirulina platensis. Biotechnol. Lett. 17, $225-228$.

Miranda M. S., Cintra R. G., Barros S. B. M. and Filho J. M. (1998), Antioxidant activity of the microalga Spirulina maxima. Brazilian J. Med. Biol. Res. 31, 1075-1079.

Quoc K., Dubacq J., Demandre C. and Mazliak P. (1994), Comparative effects of exogenous fatty acid supplementations on the lipids from the cyanobacterium Spirulina platensis. Plant Physiol. Biochem. 32 (4), 501-509.

Richmond A. (1990), Handbook of Microalgal Mass Culture. CRC Press, Boca Raton, FL. ISBN 0-84933240-0.

Richmond A. (1988), Micro-algal Biotechnology. Cambridge University Press. ISBN 0-5213-2349-5.

Sarada R., Pillai G. and Ravishankar G. A. (1999), Phycocyanin from Spirulina sp: influence of processing of biomass on phycocyanin yield, analysis of efficacy of extraction methods and stability studies on phycocyanin. Process Biochem. 34, 795-801.

Vonshak A. (1997), Spirulina platensis (Arthrospira): Physiology, Cell Biology and Biotechnology. Taylor \& Francis, London. ISBN 0-7484-0674-3.

Vonshak A., Abeliovich A., Boussiba S., Arad S. and Richmond A. (1982), Production of Spirulina biomass: effects of environmental factors and population density. Biomass 2, 175-185.

Zar J. H. (1984), Biostatistical Analysis, Prentice Hall, Englewood Cliffs, NJ.

Zarrouk C. (1966), Contribution à l'étude d'une cyanophycée. Influence de divers facteurs physiques et chimiques sur la croissance et la photosynthèse de Spirulina maxima. $\mathrm{Ph}$. D. Thesis, Paris.

Zhang X. W., Chen F. and Johns M. (1999), Kinetic models for heterotrophic growth of chlamydomonas reinhardtii in batch and fed-batch cultures. Process Biochem. 35, 385-389.

Zhang X. W., Zhang Y. M. and Chen F. (1999), Application of mathematical models to the determination optimal glucose concentration and light intensity for mixotrophic culture of Spirulina platensis. Process Biochem. 34, 477-481. 